I am glad to say that the liaison between this newly formed department and the Ceylon Game and Fauna Protection Society is working well. They have a difficult and arduous task before them, especially in respect of stamping out illicit shooting in the close seasons. The export of Elephants has been prohibited, except by Government; the Zoological Gardens have recently exported a few Elephants in exchange for other animals.

Neither crocodile skins nor deer horns are allowed to be exported. A large trade was carried on in the latter under the guise of " shed horns ", but after representations had been made by the Ceylon Game and Fauna Protection Society, pointing out the very great number of stags the exported weight of horns represented, Government banned this export.

If public opinion can be sufficiently aroused and the people educated to become more wild life minded, then the wild life of Ceylon will be saved for further generations.

\title{
MAN AND THE ZEBRA
}

\section{By J. I. Menzies}

The African fauna has been subjected to pressure from two far distant sources. In the north the well armed Moors and Arabs have long ruled the land, and it is in this region that the faunal population has been most seriously depleted. The Atlantic Ass, depicted in Roman mosaics, disappeared long ago, the Rufous Gazelle and Bubal Hartebeeste have likewise vanished.

The zebras, however, have not been greatly affected from this region although it is interesting to note that the Romans exhibited zebras in their amphitheatres and must presumably have obtained them from north-east Africa. Dion Cassius, speaking of Plautonius, says : "he even took from one of the islands in the Red Sea the horses of the sun resembling tigers- " and also "-for the elephant indeed, and the rhinoceros and the tiger and the hippotigris slain in the theatre ".

The second assault upon the African fauna commenced with Van Riebeck's settlement in the Cape in 1652. As the white population increased by immigration, so the fauna decreased. Such species as the Blaauwbuck soon became extinct and other species became reduced or exterminated, first in the Cape, later in the Orange Free State and other colonies. Less than fifty years after the Great Trek of 1835, which began the extensive 
settlement beyond the Orange, the Quagga was finally wiped out.

Between the Portuguese discovery, Dutch settlement, and English conquest the fauna of South Africa has suffered considerably.

The major portion of the African continent between the two spheres of white influence has only comparatively recently been affected. It is enlightening to note that, so far, no species of Central African mammals have been exterminated.

The zebras include those species of Equidae more or less marked with alternate dark and light bands. They fall into three groups.

The first group is constituted by two species, Equus quagga (the Quagga) and Equus burchelli (Burchell's Zebra). The second and third group each include only one species, Equus zebra (Mountain Zebra) and Equus grevyi (Grevy's Zebra). Separate genera have been proposed for these species (Hippotigris and Dolichohippus) but these are usually regarded as sub-genera. To quote Lydekker: "The skeletons of all the living Equidae are so alike that, except for size, it appears impossible to distinguish the teeth or limb-bones of the various species from one another."

Owing to the looseness of the popular names by which the various zebras are known, each type is hereafter referred to by its scientific title. Equus quagga was first known as " wilde-esel" (wild ass) and later as quagga, or couagga, this being the Dutch equivalent of the Hottentot name. The southernmost races of Equus burchelli were also referred to as quagga, but were more properly known as "bontequagga " or "bontzebra ". The mountain zebra was known as "wilde-paard" (wild horse) but referred to as "wilde-esel " in some texts and just " zebra" in others.

Equus quagga and Equus burchelli were both plains dwelling species, often associating in immense herds with gnu and ostrich but keeping separate in the overlapping portions of their ranges. Commencing with Equus quagga (striped only on the anterior portion of the body) and passing through the several sub-species of Equus burchelli, a gradual extension of the striping can be traced culminating in the fully striped northern races. Indeed, Pocock earlier believed that Equus quagga was merely the southernmost race of Equus burchelli, as upon examining the preserved specimens of quagga considerable variation in pattern was apparent. The animal figured by Daniell was striped only upon the neck and shoulder, whereas the specimen in the Tring Museum is striped as far back as the haunch. 
The range of Equus quagga was fairly well defined, from the Kei river west at least as far as Swellendam and north to the Orange Free State and Griqualand West. Pocock believed that it did not range north of the Orange but as this river, below its junction with the Vaal, loses more water than it gains, it would seem to constitute little of a barrier.

Equus burchelli also shows a great variation in striping. Of all the numerous sub-species that have been proposed Cabrera recognizes only four as valid. The southernmost is Equus burchelli burchelli, which was found in the Orange Free State and Southern Bechuanaland but not south of the Orange River. The whole of the body was striped but not the legs, the haunch being more or less distinctly marked. Towards the posterior broad shadow stripes appear between the dark stripes.

The second sub-species is antiquorum, with the legs incompletely striped and the shadow stripes less distinct than in burchelli. This race once inhabited Southern Angola, South-West Africa, eastwards to Southern Rhodesia and Zululand.

The last two sub-species, selousii and böhmi, are fully striped to the hooves with the shadow stripes very indistinct or altogether absent. 'They range from the Limpopo northwards, east of the Rift Valley through Rhodesia, the Congo (Katanga and Ruanda), Nyasaland, Tanganyika, Kenya and Uganda, to Abyssinia and Somaliland.

The second group of zebras (Mountain Zebras) includes only one species, Equus zebra, completely striped with broad black bands. Two sub-species are recognized. Equus zebra zebra had a limited range in the mountains of the Cape Colony. Equus zebra hartmannae is now greatly restricted but was formerly found in South-West Africa along the sub-continuous chain of arid mountains bordering the western edge of the Namib desert. Frequently found on the sea shore it ascended to 7,000 feet and was rarely seen more than $\mathbf{3 0}$ miles inland. It ranged from Southern Angola across the Orange River to the Kamiesberg. Both sub-species associated only in small parties.

The third group (Grevy's Zebra) also includes only one species, Equus grevyi. This became known to science as late as 1882 although, as mentioned previously, the Romans had zebras which may have been of this species. In addition, Cornwallis Harris, writing in 1840, states that the Mountain Zebra occurs in Abyssinia and was possibly referring to the present species. These zebras appear to inhabit open, sparsely-wooded country, avoiding thick bush, and are rather localized throughout Southern Abyssinia and western Somaliland. Southwards they range into 
Kenya to the Tana River and westwards to Lake Rudolph and eastwards to the western border of Somaliland. They do not appear to occur further north than $8^{\circ}$ of latitude.

The history of Equus grevyi is brief and gives no cause for anxiety. About the seventeenth century the King of Abyssinia sent one specimen to the Governor of Batavia and one to the Sultan of Turkey. On 12th December, 1882, at a meeting of the Zoological Society of London, a skin of this species was exhibited and the differences between it and Equus zebra, with which it had formerly been classified, pointed out. This was the skin of an animal that lived for a short time in Paris and the new species was named after the French President. References to its present status are not available but it appears to be fairly numerous over its original range and in no danger of extinction.

The chronicle of man's effect upon the other two groups is, on the contrary, neither brief nor pleasant. One species (Equus quagga) and one sub-species (Equus b. burchelli) are extinct and another (Equus z. zebra) brought to the verge of extinction.

Being the most southerly of the zebras, Equus quagga was the first to suffer from the advance of civilization. Initially, quaggas existed in countless thousands, Lydekker tells of quaggas in droves. One of the earliest records tells of "long files of quaggas . . . remind . . . of a rival caravan on the march". The Boers then began their systematic exploitation. "Scarcely an hour elapsed at morning noon and evening but the distant booming of a Dutchman's gun saluted the ear." By the first quarter of the nineteenth century Lydekker's "droves" had been reduced to herds of thirty to fifty animals. By 1840 they had been driven to the borders of the Cape Colony. North of the Orange, however, they were still numerous but the exploitation for their hides continued. In addition, the farmers found the beasts a ready source of cheap meat for their native labour. Cornwallis Harris tells us "... the flesh is . . . used . . for the purpose of feeding their tame Bushmen, . . . the hides are valuable for making sacks to contain grain and the thicker portions ... for the manufacture of shoe soles ". The last two quaggas in the Cape Colony appear to have been shot on the Tygerberg Mountain, near Aberdeen, in 1850. They still lingered on, however, in the Orange Free State, possibly as late as 1878, but, far from its homeland, a single specimen lived on in the Amsterdam Zoo and died, the last survivor of its race, on the 12th September, 1883.

Several times quaggas have been reported from the Kaokoveld, South West Africa. This is almost certainly due to confusion 
with Hartmann's Zebra which appears brown when seen from a distance. The native commissioner for Ovamboland, Major C. H. Hahn, has conducted a most careful inquiry into this and has come to the conclusion that there is no truth whatsoever in these reports. To all the tribesmen he interviewed only two species of zebra are known, namely Burchell's and Hartmann's ; indeed, to some of the tribes the latter species is known as the brown zebra.

The history of Equus b. burchelli followed a similar course. We read that it once existed in immense herds "but all have long ago been swept away by the rifle". As its relative south of the Orange, this species provided a cheap supply of meat for the native labour of the progressing colonists. The corresponding periods of its history appear to lag about a quarter of a century behind those of quagga which being the time elapsing between the colonization of the Cape and subsequent settlement in the lands to the north. It is interesting to read that, so long ago as 1885, a certain Captain Lugard, examining the possibilities of its employment for draught purposes, recommended that the species be accorded complete protection. Would that his words had been heeded, for about the turn of the century, excepting a single specimen which lived on in the London Zoo until 1909, the race became extinct.

The other three sub-species of Equus burchelli are still numerous, indeed in some parts the numbers have to be kept under control to avoid damage to crops. In South West Africa antiquorum is common and far outnumbers hartmanno. Some have adapted themselves to the mountain ranges of South West Africa, occurring alongside but not associating with hartmannce. On the plains and deserts they congregate in large herds with gemsbok. In times of drought they assemble in large numbers around the Etosha Pan and other sources of water.

Farther to the north and east the races selousii and böhmi are still found. Where there is little cultivated land they are in no danger of reduction and in the various national parks and reserves provide one of the greatest attractions.

Equus zebra, with its two sub-species, zebra and hartmanno, was always a more specialized animal with a very restricted range. With the quagga, the Cape race was early subjected to the onslaught of the colonists, but owing to its inaccessible habitat was not so seriously decimated. As did the quagga, it provided cheap meat and leather for the farmers. Bryden tells us that many were "driven over the edge of cliffs to save shooting ", after this the hunters could gather the spoils at their 
leisure. Little wonder, then, that a species with such a limited distribution was soon brought to the verge of extinction. E. L. Gill, writing in the Cape Times of 1931, says : " their old haunts are marked by such names as Paardeberg and Paardekop but the name is all that remains." By 1935 it was estimated that only 100 were left alive. The species was then accorded complete protection but the numbers were still reduced by poachers. The position by January, 1937, was such that "... unless definite steps were made to take the few survivors under government protection the species would be doomed"

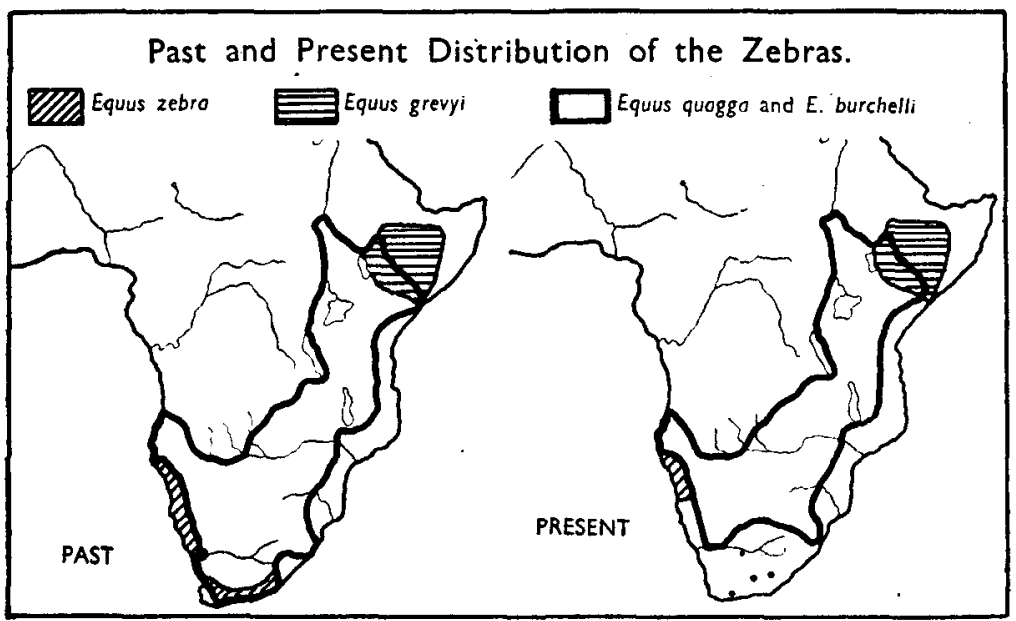

Four months later the government acted. A sum of $£ 7,600$ was voted for the establishment of a reserve to the west of Cradock, and it was proposed to transfer thirty-seven beasts, then in a state of semi-domestication on near-by farms, to the new reserve. However, between the date of foundation and 1940 we have no record of progress but in that year it is reported that a foal was born, bringing the total number up to seven! By 1949 the stock in the reserve was reduced to two stallions, which have since died. More recently, however, a new herd has been located in the Outeniqua mountains, and it was suggested that a new reserve be established there. The sum total at that time was between seventy and one hundred. Thirty-two were on the farms of Messrs. Michau and Lombard, near Cradock ; twenty to twenty-five in the Outeniqua mountains, and possibly fifteen in the Kamanassie region. On the 11th September, 1950, this 


\section{EXTINCT RACES}

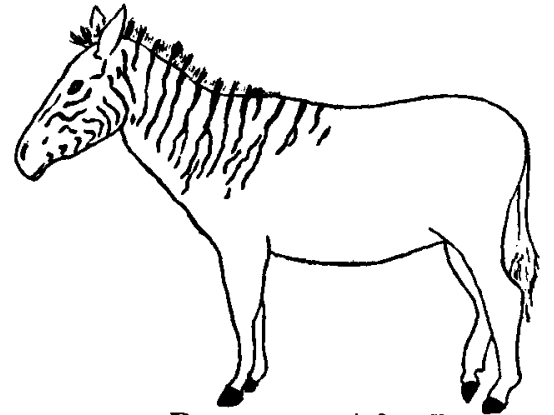

Equus quagga (after Daniel)

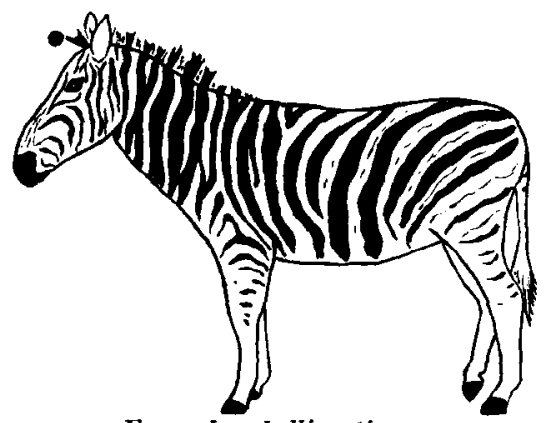

Equus burchelli antiquorum

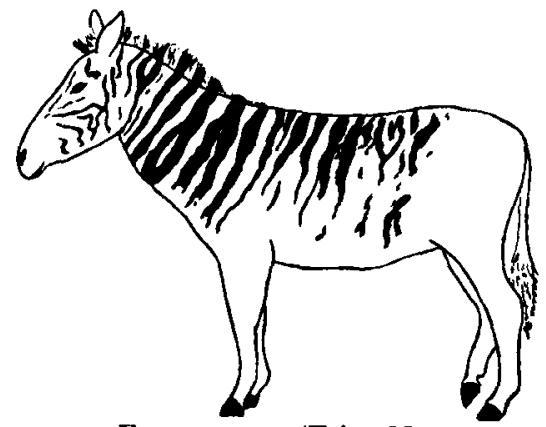

Equus quagga (Tring Museum)

LIVING RACES

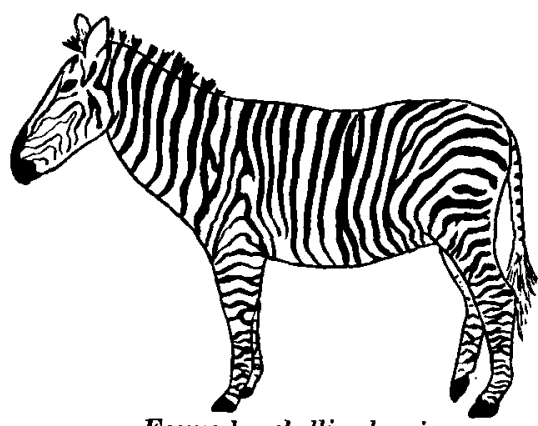

Equus burchelli selousi

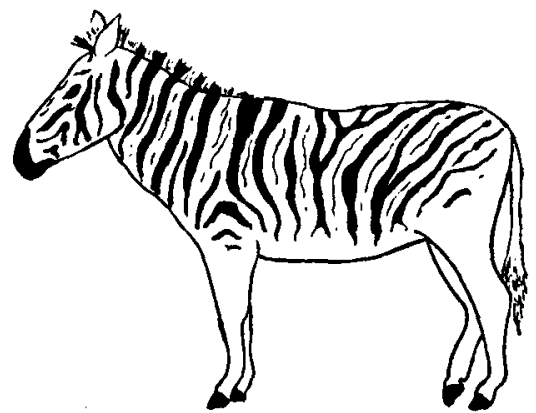

Equus burchelli burchelli

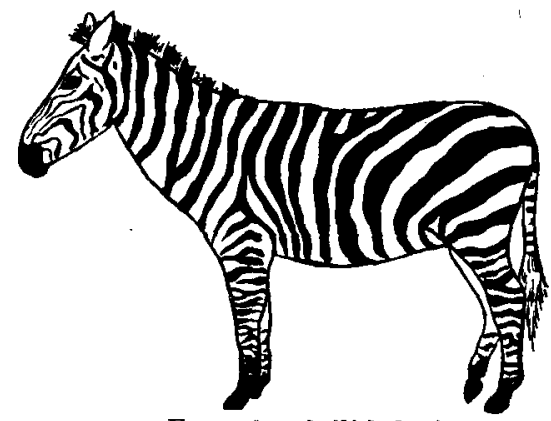

Equus burchelli böhmi

DIAGRAMMATIC REPRESENTATION OF EQUUS QUAGGA AND EQUUS BURCHELLI TO SHOW THE GRADATION IN STRIPING OF THE DIFFERENT RACES

SYSTEMATIC SUMMARY

Order : Perissodactyla-Odd-toed Ungulates.

Family : $E Q U I D A-H o r s e s$, etc.

Genus : Equus Linn.

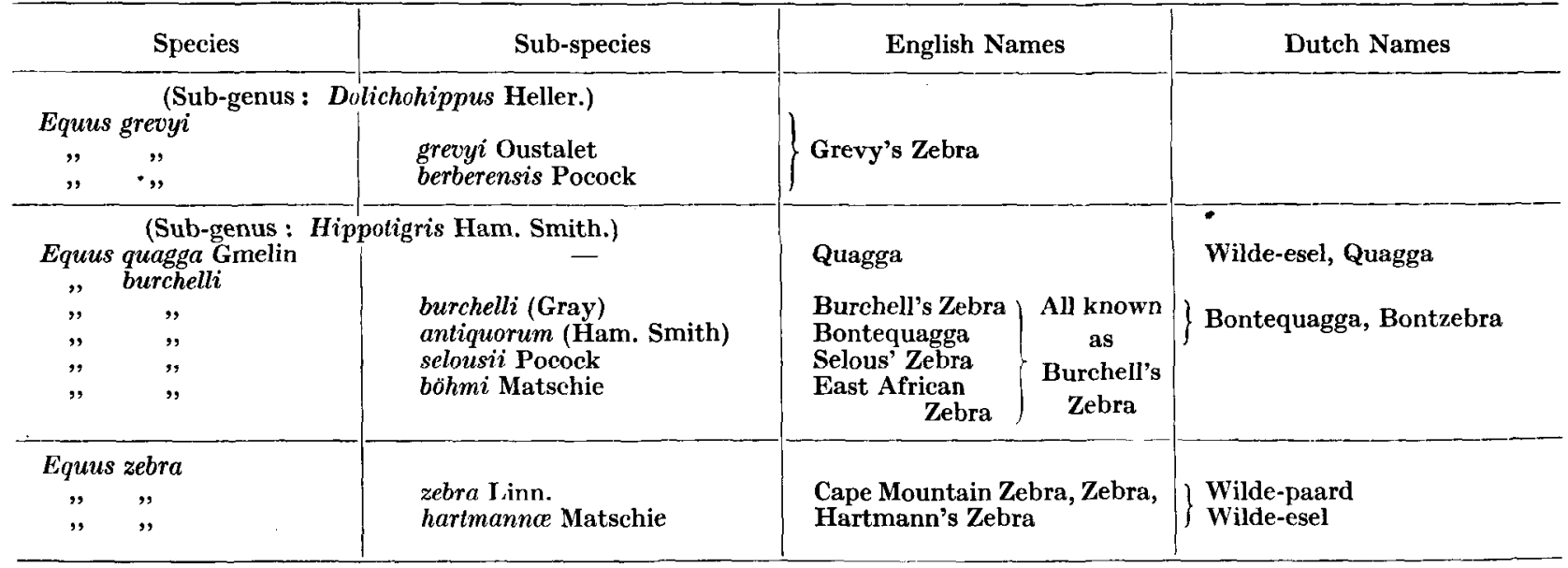


new reserve was opened, enriched by the generous gift of eleven animals from Mr. Lombard's farm. It is hoped that the future of the Cape Mountain Zebra has now been set on a firm foundation.

One last matter which, but for the introduction of the internal combustion engine, might have saved two types of zebra from extinction. The economic importance of zebras was once not merely a question of food and leather but of replacement of the horse for draught purposes. Such, indeed, was their utility that, as mentioned earlier, complete protection was advised as early as 1888. References to their being used in harness are numerous and not confined to the African continent. Several were employed in London- " in Hyde Park may be seen a curricle drawn by two couaggas". The Hon. Walter Rothschild " placed three (Burchell's Zebra) in the hands of a very careful breaker ". These were later driven in single and double harness through the streets.

In Africa many more were being trained. Messrs. Zeedesbergs, who ran a mail service between Pretoria and Mashonaland, used four zebras paired with and headed by mules to draw one of their coaches. That their ability was equal to that of horses was shown by Messrs. Zeedesbergs' intention to extend their use : ". . . it will be the means of saving them hundreds of pounds which they now lose annually through horse sickness."

Equus zebra was also used though not found as amenable to training as quagga and burchelli. That its domestication was attempted is undoubted. A certain Captain Hayes states that, in two days, he broke in an old stallion to be sufficiently quiet for his wife to ride and be photographed on.

Towards the turn of the century the references to draught zebras become fewer. One must suppose that the introduction of the petrol engine put an end to their use and incidentally sounded the death knell of Equus burchelli burchelli.

\section{REFERENCES}

HARPER, F. Extinct and Vanishing Mammals of the Old World, 1945.

LYDEKKER, R. The Game Animals of Africa, 1926.

Griffini, Dr. Achinle. Le Zebre, 1913.

Harris, W. Cornwallis. Portraits of the Game Animals of South Africa, 1840. Tegetmener, W. B., and Sutherland, C. L. Horses, Asses, Zebras, Mules, and Mule Breeding, $\mathbf{1 8 9 5 .}$

Journal of the Society for the Preservation of the Fauna of the Empire, Nos. II, VI, VII, IX, XXVIII, XXX, XXXI, XXXII, XXXIX, and XL.

$I$ am also indebted to the Wild Life Protection Society of South Africa for supplying information regarding the present status of the Cape Mountain Zebra. 